\title{
Thermohalobacter berrensis gen. nov., sp. nov., a thermophilic, strictly halophilic bacterium from a solar saltern
}

\author{
Jean-Luc Cayol, ${ }^{1}$ Sophie Ducerf, ${ }^{1}$ Bharat K. C. Patel, ${ }^{2}$ Jean-Louis Garcia, ${ }^{1}$ \\ Pierre Thomas ${ }^{3}$ and Bernard Ollivier ${ }^{1}$
}

\footnotetext{
1 IRD, Laboratoire de Microbiologie, Université de Provence, ESIL case 925, 163 Avenue de Luminy, 13288 Marseille Cedex 9, France

2 School of Biomolecular and Biomedical Sciences, Faculty of Science, Griffith University, Brisbane, Queensland 4111, Australia

3 Département de Biologie, Université de la Méditerranée, Marseille, France
}

\author{
Author for correspondence: Bernard Ollivier. Tel: +334918285 76. Fax: +33491828570. \\ e-mail: ollivier@esil.univ-mrs.fr
}

\begin{abstract}
A new thermophilic, strictly halophilic, anaerobic, non-sporulating rod-shaped bacterium, measuring $\mathbf{0 . 5} \times \mathbf{3 . 0 - 8 . 0} \mu \mathrm{m}$ and designated strain CTT3 $^{\mathrm{T}}$, was isolated from a solar saltern. Strain $\mathrm{CTT3}^{\mathrm{T}}$ stained Gram-negative, was motile by means of laterally inserted flagella, had a genome G+C content of $33 \mathrm{~mol} \%$ and grew optimally at $65{ }^{\circ} \mathrm{C}$ and pH 7.0 with $5 \% \mathrm{NaCl}$. The strain also grew readily at $70{ }^{\circ} \mathrm{C}$ in the presence of $15 \% \mathrm{NaCl}$. Strain $\mathrm{CTT}^{\mathrm{T}}$ fermented cellobiose, fructose, glucose, maltose, mannitol, mannose, sucrose, glycerol, $\boldsymbol{N}$-acetylglucosamine, starch, pyruvate and bio-Trypticase. It produced acetate, ethanol, $\mathrm{H}_{2}$ and presumably $\mathrm{CO}_{2}$ from glucose. 16S rRNA gene sequence analysis indicated that it is a member of cluster XII of the Clostridiales and related genera of the subphylum of the Gram-positive bacteria containing genomes of low $\mathbf{G}+\mathbf{C}$ content. Its phenotypic and phylogenetic characteristics clearly differentiated it from all other members of this cluster. Based on the findings it is proposed that strain $\mathrm{CTT3}^{\mathrm{T}}$ be designated as a new species of a new genus, Thermohalobacter berrensis gen. nov., sp. nov. The type strain is CTT3 ${ }^{\mathrm{T}}$ (= CNCM 105955').
\end{abstract}

Keywords: Thermohalobacter berrensis, halophily, thermophily, taxonomy, solar saltern

\section{INTRODUCTION}

Scientific interest in extremophilic anaerobic microorganisms has recently increased due to the possible biotechnological uses of enzymes and molecules of thermophiles (Klingeberg et al., 1991; Lowe et al., 1993; Zamost et al., 1991; Zeikus, 1979). Although a diverse range of physiological groups of thermophiles, including acidophiles, alkaliphiles, neutrophiles, aerobes and anaerobes of the domain Bacteria, have been studied and reported in the literature, very little is known about halophilic thermophiles. The halophilic thermophilic heterotrophic bacteria that have been studied to date require $\mathrm{NaCl}$ concentrations lower than $5 \%$ for optimal growth and can therefore rather be considered as haloduric (Davey et al., 1993; Huber et al., 1986, 1989; Larsen, 1962). The anaerobic halophiles in the order Haloanaerobiales are divided into two families: Haloanaerobiaceae and Halo-

The GenBank accession number for the 16S rRNA gene sequence of strain $\mathrm{CTT}^{\mathrm{T}}{ }^{\mathrm{T}}$ is AF113543. bacteroidaceae. They are moderate halophiles (Oren, 1986; Zhilina et al., 1991), mostly thermotolerant, but unable to grow at or above $60{ }^{\circ} \mathrm{C}$, with the exception of Halothermothrix orenii, a member of the family Haloanaerobiaceae (Cayol et al., 1994). Halothermothrix orenii is a heterotrophic bacterium, isolated from a Tunisian salt lake, that grows optimally at $60^{\circ} \mathrm{C}$ in $\mathrm{NaCl}$ concentrations ranging from 50 to $100 \mathrm{~g} \mathrm{l}^{-1}$, with an upper limit of $200 \mathrm{~g} \mathrm{NaCl}^{-1}$.

We report in this paper the description of strain $\mathrm{CTT}^{\mathrm{T}}$ isolated from a solar saltern in France. This is the first description of a true anaerobic, moderately halophilic and thermophilic bacterium, phylogenetically related to the Clostridiales. Based on our findings, we propose that strain $\mathrm{CTT} 3^{\mathrm{T}}$ be designated as a new species of a new genus, Thermohalobacter berrensis gen. nov., sp. nov.

\section{METHODS}

Collection site. Strain CTT3 ${ }^{\mathrm{T}}$ was isolated from a sediment sample collected from a canal of a solar saltern near Berre Lagoon, southern France. The $\mathrm{NaCl}$ concentration was $20 \mathrm{~g}$ 
$1^{-1}$. The sample was transported to our laboratory and stored at $4{ }^{\circ} \mathrm{C}$ until used.

Culture media, enrichment and isolation procedure. Enrichment and isolation were performed using a growth medium which contained (per litre distilled water): $\mathrm{NH}_{4} \mathrm{Cl}$, $0.1 \mathrm{~g} ; \mathrm{K}_{2} \mathrm{HPO}_{4}, 0.3 \mathrm{~g} ; \mathrm{KH}_{2} \mathrm{PO}_{4}, 0.3 \mathrm{~g} ; \mathrm{MgCl}_{2}, 2 \mathrm{~g} ; \mathrm{CaCl}_{2}$, $0.2 \mathrm{~g} ; \mathrm{CH}_{3} \mathrm{COONa}, 0.5 \mathrm{~g}$; $\mathrm{NaCl}, 100 \mathrm{~g} ; \mathrm{KCl}, 4 \mathrm{~g}$; glucose, $10 \mathrm{~g}$; cysteine $/ \mathrm{HCl}, 0.5 \mathrm{~g}$; yeast extract (Difco), $1 \mathrm{~g}$; bioTrypticase (BioMérieux), $1 \mathrm{~g}$; trace mineral element solution (Imhoff-Stuckle \& Pfennig, 1983), $1 \mathrm{ml}$; resazurin, $1 \mathrm{mg}$. The $\mathrm{pH}$ was adjusted to $7 \cdot 0$ with $10 \mathrm{M} \mathrm{KOH}$, after which the medium was boiled under a stream of $\mathrm{O}_{2}$-free $\mathrm{N}_{2}$ gas and cooled to room temperature. Five or $20 \mathrm{ml}$ aliquots were dispensed into Hungate tubes or serum bottles, respectively, under a stream of $\mathrm{N}_{2} / \mathrm{CO}_{2}(80: 20 \mathrm{v} / \mathrm{v})$ and the vessels were autoclaved for $45 \mathrm{~min}$ at $110^{\circ} \mathrm{C}$. Prior to inoculation, $\mathrm{Na}_{2} \mathrm{~S} .9 \mathrm{H}_{2} \mathrm{O}$ and $\mathrm{NaHCO}_{3}$ were injected from sterile stock solutions to obtain a final concentration of 0.04 and $0 \cdot 2 \%$ $(\mathrm{w} / \mathrm{v})$, respectively.

For initiating enrichment cultures, a small portion of the sediment sample was inoculated into growth medium followed by incubation at $62{ }^{\circ} \mathrm{C}$ without agitation. The culture was purified by repeated use of the Hungate roll tube method (Hungate, 1969; Macy et al., 1972; Miller \& Wolin, 1974) in growth medium amended with $2 \%(\mathrm{w} / \mathrm{v})$ agar (Difco).

Characterization. $\mathrm{pH}$, temperature and $\mathrm{NaCl}$ ranges for growth were determined in growth medium. The medium in Hungate tubes was adjusted to the desired $\mathrm{pH}$ values (between 4.8 and $9 \cdot 0$ ) by injecting $\mathrm{NaHCO}_{3}$ or $\mathrm{Na}_{2} \mathrm{CO}_{3}$ from $10 \%(\mathrm{w} / \mathrm{v})$ sterile anaerobic stock solutions. For studies on $\mathrm{NaCl}$ requirements, different amounts of $\mathrm{NaCl}$ were weighed directly into Hungate tubes (to obtain final $\mathrm{NaCl}$ concentrations of $1-20 \%$ ) prior to dispensing $5 \mathrm{ml}$ growth medium. The strain was subcultured at least once under the same experimental conditions prior to determination of growth rates. Substrates were tested at a final concentration of $20 \mathrm{mM}$ in growth medium that lacked glucose. To test for electron acceptors, sodium thiosulfate, sodium sulfate and elemental sulfur were added to the growth medium at final concentrations of $20 \mathrm{mM}, 20 \mathrm{mM}$ and $2 \%(\mathrm{w} / \mathrm{v})$, respectively.

Sporulation test. The heat resistance of cells was determined in growth medium. After 1 and $2 \mathrm{~d}$ incubation at $65^{\circ} \mathrm{C}$, duplicated cultures were heated at 90 or $100{ }^{\circ} \mathrm{C}$ for $20 \mathrm{~min}$ and subcultured into fresh growth medium $(20 \%, \mathrm{v} / \mathrm{v}$, inoculum). The resulting cultures were incubated at $65^{\circ} \mathrm{C}$ for $2 \mathrm{~d}$. In addition, cultures grown (i) in the basal medium or (ii) in the basal medium enriched with $5 \mathrm{~g}$ yeast extract $1^{-1}$ and bio-Trypticase were examined for the presence of spores at different growth phases.

Analytical techniques. Techniques used for light and electron microscopy have been described previously (Fardeau et al., 1997). Unless otherwise indicated, duplicate culture tubes were used throughout these studies. Growth was measured by inserting tubes directly into a model UV-160A spectrophotometer (Shimadzu) and measuring the $\mathrm{OD}_{580}$. Sulfide was determined photometrically as colloidal $\mathrm{CuS}$ by using the method of Cord-Ruwisch (1985). $\mathrm{H}_{2}, \mathrm{CO}_{2}$, sugars, alcohols, volatile and non-volatile fatty acids were measured as described previously (Cayol et al., 1995).

Determination of $\mathbf{G}+\mathbf{C}$ content. The $\mathrm{G}+\mathrm{C}$ content of the DNA was determined by the Deutsche Sammlung von
Mikroorganismen und Zellkulturen GmbH (DSMZ), Braunschweig, Germany. DNA was isolated and purified by chromatography on hydroxyapatite and its $\mathrm{G}+\mathrm{C}$ content was determined by using HPLC as described by Mesbah et al. (1989). Non-methylated $\lambda$ DNA (Sigma) was used as the standard.

$16 S$ rRNA gene sequence analysis. The methods for the purification and extraction of DNA and the amplification and sequencing of the 16S rRNA gene have been described previously (Andrews \& Patel, 1996). The 16S rRNA gene sequence was manually aligned with reference sequences of various members of the domain Bacteria using the editor ae 2 (Maidak et al., 1996). Reference sequences were obtained from the Ribosomal Database Project (Maidak et al., 1996), EMBL and GenBank databases. Positions of sequence and alignment uncertainty were omitted from the analysis. The pairwise evolutionary distances based on 1124 unambiguous nucleotides were computed by using the method of Jukes \& Cantor (1969) and dendrograms were constructed from these distances by using the neighbour-joining method, both of which from part of the PHYLIP suite of programs (Felsenstein, 1993).

\section{RESULTS}

\section{Enrichment and isolation}

Enrichment cultures were positive after $3 \mathrm{~d}$ incubation at $62{ }^{\circ} \mathrm{C}$. Microscopic examination revealed the presence of rod-shaped bacteria. Colonies $1 \mathrm{~mm}$ in diameter developed in roll tubes after $48 \mathrm{~h}$ incubation at $62{ }^{\circ} \mathrm{C}$. Single colonies were picked and tenfold serial dilutions in roll tubes were repeated at least twice before the culture was considered pure. Though several axenic cultures were obtained using this procedure, only one strain, designated $\mathrm{CTT}^{\mathrm{T}}$, was used for further characterization.

\section{Morphology}

Strain $\mathrm{CTT}^{\mathrm{T}}$ was a conventional rod-shaped bacterium, measuring $0.5 \times 3 \cdot 0-8 \cdot 0 \mu \mathrm{m}$, which grew singly or in pairs. The cells were motile with laterally inserted flagella and stained Gram-negative. Electron microscopy of thin sections of strain $\mathrm{CTT} 3^{\mathrm{T}}$ revealed a cell wall ultrastructure typical of Gram-negative bacteria (Fig. 1). Despite spores not being observed under different growth conditions and at different growth phases, cells survived pasteurization at $100{ }^{\circ} \mathrm{C}$ for $20 \mathrm{~min}$, thus suggesting the presence of heat-resistant forms.

\section{Optimum growth conditions}

Strain $\mathrm{CTT}^{\mathrm{T}}$ did not grow in anaerobic medium that contained traces of oxygen (as indicated by the pink colour of the resazurin in the growth medium) and was therefore ascribed as a strict anaerobe. It grew at temperatures ranging from 45 to $70{ }^{\circ} \mathrm{C}$, with an optimum at $65^{\circ} \mathrm{C}$ at $\mathrm{pH} 7 \cdot 0$ (Fig. 2a). The isolate grew in the presence of $\mathrm{NaCl}$ concentrations ranging from 2 to $15 \%$, with an optimum of $5 \% \mathrm{NaCl}$ at $\mathrm{pH} 7 \cdot 0$ and 


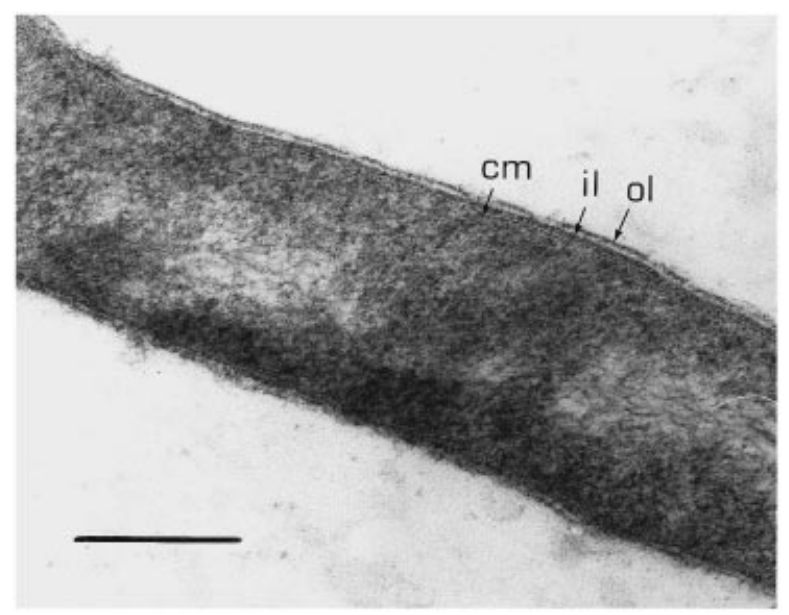

Fig. 1. Electron micrograph of an ultrathin section of strain $\mathrm{CTT3}^{\top}$ showing the cytoplasmic membrane $(\mathrm{cm})$ and the thin bilayered cell wall structure typical of Gram-negative cells, comprising the inner cell wall layer (il) associated with the cytoplasmic membrane and the outer wall layer (ol). Bar, $0.2 \mu \mathrm{m}$.

$65^{\circ} \mathrm{C}$ (Fig. 2b). Growth occurred between $\mathrm{pH} 5 \cdot 2$ and $8 \cdot 8$ at $65^{\circ} \mathrm{C}$, with an optimum $\mathrm{pH}$ of $7 \cdot 0$ (Fig. 2c). The doubling time under optimal growth conditions was $0 \cdot 46 \mathrm{~h}$.

\section{Substrates used for growth}

Yeast extract or bio-Trypticase was required for growth on carbohydrates. Strain $\mathrm{CTT} 3^{\mathrm{T}}$ grew on the following substrates $(20 \mathrm{mM})$ : cellobiose, fructose, glucose, maltose, mannose, mannitol, sucrose, glycerol, $N$-acetylglucosamine, starch, pyruvate and bio-Trypticase. It could not utilize arabinose, galactose, lactose, melibiose, raffinose, rhamnose, ribose, sorbose, trehalose, xylose, glycine betaine, fatty acids (formate, acetate, fumarate and lactate), Casamino acids, cellulose and yeast extract. Acetate, ethanol, $\mathrm{H}_{2}$ and presumably $\mathrm{CO}_{2}$ were produced during glucose fermentation. Strain CTT3 ${ }^{\mathrm{T}}$ did not reduce thiosulfate, sulfate or sulfur into sulfide.

\section{$\mathbf{G}+\mathbf{C}$ content}

The $\mathrm{G}+\mathrm{C}$ content of strain $\mathrm{CTT}^{\mathrm{T}}$ was $33 \mathrm{~mol} \%$.

\section{S rRNA gene sequence analysis}

Using 12 primers, we determined 1521 bases (corresponding to Escherichia coli positions 14-1539) of the 16S rRNA gene sequence of strain CTT3 ${ }^{\mathrm{T}}$. Phylogenetic analysis revealed that strain $\mathrm{CTT}^{\mathrm{T}}$ was a member of cluster XII of the Clostridium subphylum and its closest relatives were 'Eubacterium thermomarinus' (92\% similarity), Clostridium acidiurici $(90 \%$ similarity), Clostridium purinolyticum (90\% similarity)
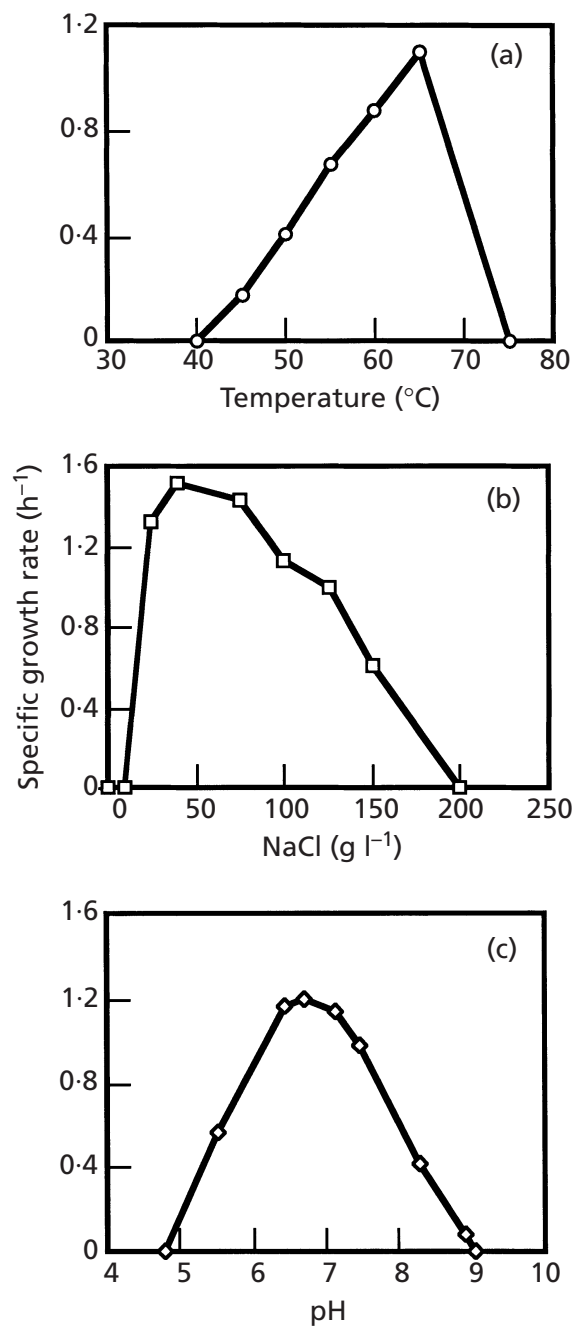

Fig. 2. Effect of temperature at $\mathrm{pH} 7.0$ and $5 \% \mathrm{NaCl}(\mathrm{a})$, effect of $\mathrm{NaCl}$ concentration at $\mathrm{pH} 7.0$ and $65^{\circ} \mathrm{C}$ (b) and effect of $\mathrm{pH}$ at $65{ }^{\circ} \mathrm{C}$ and $5 \% \mathrm{NaCl}$ (c) on the growth of strain $\mathrm{CTT}^{\top}$.

and Eubacterium angustum (90\% similarity). Fig. 3 presents a dendrogram generated by the neighbourjoining method (Felsenstein, 1993) from the JukesCantor evolutionary similarity matrix (Jukes \& Cantor, 1969).

\section{DISCUSSION}

Strain $\mathrm{CTT}^{\mathrm{T}}$ is a heterotrophic, moderately halophilic member of the domain Bacteria. Within this domain, moderate halophilism is the main characteristic shared by members of the family Haloanaerobiaceae with the exception of Haloanaerobium lacusrosei, an extreme halophilic bacterium isolated from Retba lake in Senegal (Africa) (Cayol et al., 1995). Strain CTT3 ${ }^{\mathrm{T}}$ is also a strict thermophile growing optimally at $65^{\circ} \mathrm{C}$. The family Haloanaerobiaceae is comprised exclusively mesophilic to thermotolerant micro-organisms (Ollivier et al., 1994), Halothermothrix orenii being the 


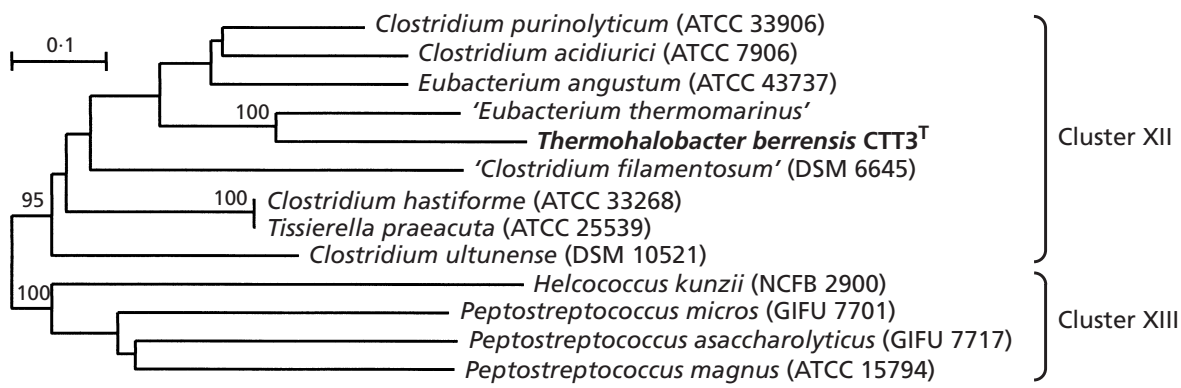

Fig. 3. Dendrogram indicating the position of strain $C T T 3^{\top}$ amongst the members of cluster XII of the low-G $+\mathrm{C}$ containing Gram-positive bacteria. The clusters are defined based on the guidelines described by Collins et al. (1994). Sequences were obtained from the Ribosomal Database Project, version 7.0 (Maidak et al., 1996). The strains listed in inverted commas have no current taxonomic standing. Bootstrap values, expressed as a percentage of 100 replications, are shown at branching points. Only values above $95 \%$ were considered significant and reported. Scale bar indicates $10 \mathrm{nt}$ substitutions per $100 \mathrm{nt}$.

only true thermophile belonging to this family and growing up to $68^{\circ} \mathrm{C}$ (Cayol et al., 1994) (Table 1). Due to its typical salt requirement, strain CTT3 ${ }^{\mathrm{T}}$ is related neither to members of the genus Thermoanaerobacter, which are described as halotolerant micro-organisms (Lee et al., 1993), nor to those of the order Thermotogales. Indeed, Thermotoga maritima and Thermotoga neapolitana are hyperthermophilic, slightly halophilic micro-organisms that do not grow at $\mathrm{NaCl}$ concentrations above 3.75 and $6 \%$, respectively (Huber et al., 1986; Windberger et al., 1989). In addition, the thermophilic Geotoga and Petrotoga species within this order do not grow in the presence of $12.5 \% \mathrm{NaCl}$ (Davey et al., 1993). The lack of lactate production from glucose by strain $\mathrm{CTT}^{\mathrm{T}}$ also rules out any similarity with the thermophilic Thermotoga or Thermoanaerobacter species cited above as all produce lactate. Finally, in contrast to strain CTT $3^{\mathrm{T}}$, Geotoga and Petrotoga species reduce elemental sulfur to sulfide and have a lower optimum temperature for growth (Davey et al., 1993; Lien et al., 1998). Interestingly, the growth temperature optimum for strain CTT $3^{\mathrm{T}}\left(65^{\circ} \mathrm{C}\right)$ is higher than that of any moderately to extremely halophilic microbe reported to date, including the extremely halophilic, thermophilic archaeon Methanohalobium evestigatum (Zhilina \& Zavarzin, 1987) and the moderately halophilic, thermophilic bacterium, Halothermothrix orenii (Cayol et al., 1994).

Taking into account all these observations, the closest phenotypic relative of strain CTT $^{\mathrm{T}}$ is Halothermothrix orenii. However the 16S rRNA gene sequence analysis indicates that it is not a member of the Haloanaerobiaceae but a new member of cluster XII of the Clostridiales (Collins et al., 1994), which comprises four Clostridium species (Clostridium hastiforme, Clostridium acidiurici, Clostridium purinolyticum and 'Clostridium filamentosum') and one Eubacterium species, 'Eubacterium thermomarinus'. The latter two species are not validated, have no formal description and are not available from culture collections. None of these species are reported as thermophilic and/or halophilic micro-organisms. The only moderately halophilic micro-organism so far described within the genus Clostridium is Clostridium halophilum, but it does not grow at $50^{\circ} \mathrm{C}$ (Fendrich et $a l ., 1990)$ and is phylogenetically related to cluster XI of the Clostridiales (Collins et al., 1994). Because of the combined thermophilic and moderately halophilic nature of strain $\mathrm{CTT}^{\mathrm{T}}$ and due to its phylogenetic characteristics, we propose to assign it as a new species of a new genus within cluster XII of the Clostridiales, named Thermohalobacter berrensis gen. nov., sp. nov.

This terrestrial isolate is, after Halothermothrix orenii, order Haloanaerobiales, the second thermophilic, moderately halophilic anaerobe so far described. It extends the knowledge of the biodiversity of halophilic anaerobes, which is still far from fully elucidated.

\section{Description of Thermohalobacter gen. nov.}

Thermohalobacter (Ther.mo.ha.lo.bac'ter. Gr. adj. thermos hot; Gr. n. hal salt; M.L. bacter masc. equivalent of Gr. neut. n. bakterion rod or staff; M.L. fem. n. Thermohalobacter, a thermophilic, halophilic rod).

Rod-shaped bacterium staining Gram-negative. Chemo-organotrophic and obligately anaerobic member of the domain Bacteria. Halophilic and thermophilic. Ferments sugars. External electron acceptors are not used. Member of cluster XII of the Clostridium subphylum.

\section{Description of Thermohalobacter berrensis sp. nov.}

Thermohalobacter berrensis (ber.ren'sis. N.L. adj. berrensis pertaining to Berre, southern France).

Cells are rods $(0 \cdot 5 \times 3-8 \mu \mathrm{m})$. Cells stain Gram-negative, occur singly or in pairs and possess laterally inserted flagella. Spores are not observed under different growth conditions or at different growth phases. Round colonies (1 $\mathrm{mm}$ diam.) are present after 
Table 1. Salient features of strain $\mathrm{CTT}^{\top}$ and Halothermothrix orenii

\begin{tabular}{|c|c|c|}
\hline Characteristic & $\begin{array}{c}\text { Halothermothrix } \\
\text { orenii }^{*}\end{array}$ & Strain CTT3 $^{\mathrm{T}}$ \\
\hline Motility & + & + \\
\hline $\mathrm{NaCl}$ concentration range $(\%)$ & $4-20$ & $2-15$ \\
\hline Optimum $\mathrm{NaCl}$ concentration $(\%)$ & 10 & 5 \\
\hline Temperature range $\left({ }^{\circ} \mathrm{C}\right)$ & $45-68$ & $45-70$ \\
\hline Optimum temperature $\left({ }^{\circ} \mathrm{C}\right)$ & 60 & 65 \\
\hline $\mathrm{pH}$ range & $5 \cdot 5-8 \cdot 2$ & $5 \cdot 2-8 \cdot 8$ \\
\hline Optimum $\mathrm{pH}$ & $6 \cdot 5-7 \cdot 0$ & $7 \cdot 0$ \\
\hline Habitat & $\begin{array}{c}\text { Chott El Guettar, } \\
\text { Tunisia }\end{array}$ & $\begin{array}{c}\text { Berre Lagoon, } \\
\text { France }\end{array}$ \\
\hline $\mathrm{G}+\mathrm{C}$ content $(\mathrm{mol} \%)$ & 40 & 33 \\
\hline \multicolumn{3}{|l|}{ Substrates used: } \\
\hline Arabinose & + & - \\
\hline Cellobiose & + & + \\
\hline Fructose & + & + \\
\hline Galactose & + & - \\
\hline Glucose & + & + \\
\hline Melibiose & + & - \\
\hline Maltose & - & + \\
\hline Mannitol & - & + \\
\hline Mannose & + & + \\
\hline Starch & + & + \\
\hline Sucrose & - & + \\
\hline Ribose & + & - \\
\hline Xylose & + & - \\
\hline Glycerol & - & + \\
\hline$N$-Acetylglucosamine & ND & + \\
\hline Pyruvate & - & + \\
\hline Bio-Trypticase & - & + \\
\hline $\begin{array}{l}\text { End products from glucose } \\
\text { fermentation }\end{array}$ & $\begin{array}{l}\text { Acetate, ethanol, } \\
\qquad \mathrm{H}_{2}, \mathrm{CO}_{2}\end{array}$ & $\begin{array}{l}\text { Acetate, ethanol, } \\
\qquad \mathrm{H}_{2}, \mathrm{CO}_{2}\end{array}$ \\
\hline
\end{tabular}

* Data from Cayol et al. (1994). ND, Not determined.

$2 \mathrm{~d}$ incubation at $62^{\circ} \mathrm{C}$. Chemo-organotrophic and obligately anaerobic member of the domain Bacteria. Optimum temperature for growth is $65^{\circ} \mathrm{C}$ at $\mathrm{pH} 7 \cdot 0$; growth occurs between 45 and $70^{\circ} \mathrm{C}$. The optimum $\mathrm{pH}$ is 7.0 at $65^{\circ} \mathrm{C}$; growth occurs between $\mathrm{pH} 5.2$ and 8.8. Optimum $\mathrm{NaCl}$ concentration for growth is $5 \%$ at $65^{\circ} \mathrm{C}, \mathrm{pH} \mathrm{7.0}$; growth occurs at $\mathrm{NaCl}$ concentrations ranging from 2 to $15 \%$. Ferments cellobiose, fructose, glucose, maltose, mannose, mannitol, sucrose, glycerol, $N$-acetylglucosamine, starch, pyruvate and bio-Trypticase, but not arabinose, galactose, lactose, melibiose, raffinose, rhamnose, ribose, sorbose, trehalose, xylose, glycine betaine, fatty acids (formate, acetate, fumarate and lactate), Casamino acids, cellulose and yeast extract. Acetate, ethanol, $\mathrm{H}_{2}$ and presumably $\mathrm{CO}_{2}$ are produced during glucose fermentation. Elemental sulfur, sulfate and thiosulfate cannot be used as electron acceptor. The $\mathrm{G}+\mathrm{C}$ content of the DNA is $33 \mathrm{~mol} \%$ (HPLC). Isolated from sediment of a feeding canal of a solar saltern. The type strain is $\mathrm{CTT}^{\mathrm{T}}\left(=\mathrm{CNCM} 105955^{\mathrm{T}}\right)$.

\section{ACKNOWLEDGEMENTS}

We are indebted to $\mathrm{H}$. Cabardos for sampling the sediment and P. A. Roger for improving the manuscript. Australian Research Council is gratefully acknowledged for part funding of the research presented in this communication (to B.K.C.P.).

\section{REFERENCES}

Andrews, K. T. \& Patel, B. K. C. (1996). Fervidobacterium gondwanense sp. nov., a new thermophilic anaerobic bacterium isolated from nonvolcanically heated geothermal waters of the Great Artesian Basin of Australia. Int J Syst Bacteriol 46, 265-269.

Cayol, J.-L., Ollivier, B., Patel, B. K. C., Prensier, G., Guezennec, J. \& Garcia, J.-L. (1994). Isolation and characterization of Halothermothrix orenii gen. nov., sp. nov., a halophilic, thermophilic, fermentative, strictly anaerobic bacterium. Int $J$ Syst Bacteriol 44, 534-540.

Cayol, J.-L., Ollivier, B., Patel, B. K. C., Ageron, E., Grimont, P. A. D., Prensier, G. \& Garcia, J.-L. (1995). Haloanaerobium lacusroseus sp. nov., an extremely halophilic fermentative bacterium 
from the sediments of a hypersaline lake. Int $J$ Syst Bacteriol 45, 790-797.

Collins, M. D., Lawson, P. A., Willems, A., Cordoba, J. J., Fernandez-Garayzabal, J., Garcia, P., Cai, J., Hippe, H. \& Farrow, J. A. E. (1994). The phylogeny of the genus Clostridium: proposal of five new genera and eleven new species combinations. Int $J$ Syst Bacteriol 44, 812-826.

Cord-Ruwisch, R. (1985). A quick method for the determination of dissolved and precipitated sulfides in cultures of sulfatereducing bacteria. J Microbiol Methods 4, 33-36.

Davey, M. E., Wood, W. A., Key, R., Nakamura, K. \& Stahl, D. A. (1993). Isolation of three species of Geotoga and Petrotoga: two new genera, representing a new lineage in the bacterial line of descent distantly related to the 'Thermotogales'. Syst Appl Microbiol 16, 191-200.

Fardeau, M.-L., Ollivier, B., Patel, B. K. C., Magot, M., Thomas, P., Rimbault, A., Rocchiccioli, F. \& Garcia, J.-L. (1997). Thermotoga hypogea sp. nov., a xylanolytic, thermophilic bacterium from an oil-producing well. Int J Syst Bacteriol 47, 1013-1019.

Felsenstein, J. (1993). PHYLIP (Phylogeny Inference Package) version 3.5.1c. Seattle: Department of Genetics, University of Washington.

Fendrich, C., Hippe, H. \& Gottschalk, G. (1990). Clostridium halophilum sp. nov. and $C$. litorale sp. nov., an obligate halophilic and a marine species degrading betaine in the Stickland reaction. Arch Microbiol 154, 127-132.

Huber, R., Langworthy, T. A., König, H., Thomm, M., Woese, C. R., Sleytr, U. B. \& Stetter, K. O. (1986). Thermotoga maritima sp. nov. represents a new genus of unique extremely thermophilic eubacteria growing up to $90^{\circ} \mathrm{C}$. Arch Microbiol 144, 324-333.

Huber, R., Woese, C. R., Langworthy, T. A., Fricke, H. \& Stetter, K. O. (1989). Thermosipho africanus gen. nov. represents a new genus of thermophilic eubacteria within the 'Thermotogales'. Syst Appl Microbiol 12, 32-37.

Hungate, R. E. (1969). A roll-tube method for the cultivation of strict anaerobes. Methods Microbiol 3B, 117-132.

Imhoff-Stuckle, D. \& Pfennig, N. (1983). Isolation and characterization of a nicotinic acid-degrading sulfate-reducing bacterium, Desulfococcus niacini sp. nov. Arch Microbiol 136, 194-198.

Jukes, T. H. \& Cantor, C. R. (1969). Evolution of protein molecules. In Mammalian Protein Metabolism, vol. 3, pp. 21-132. Edited by H. N. Munro. New York: Academic Press.

Klingeberg, M., Hashwa, F. \& Antranikian, G. (1991). Properties of extremely thermostable proteases from anaerobic hyperthermophilic bacteria. Appl Microbiol Biotechnol 34, 715-719.

Larsen, H. (1962). Halophilism. In The Bacteria: a Treatise on Structure and Function, vol. 4, pp. 297-342. Edited by I. C. Gunsalus \& R. C. Stanier. New York: Academic Press.

Lee, Y. E., Jain, M. K., Lee, C., Lowe, S. E. \& Zeikus, J. G. (1993).
Taxonomic distinction of saccharolytic anaerobes: description of Thermoanaerobacterium xylanolyticum gen. nov., sp. nov., and Thermoanaerobacterium saccharolyticum gen. nov., sp. nov.; reclassification of Thermoanaerobium brockii, Clostridium thermosulfurogenes, and Clostridium thermohydrosulfuricum E100-69 as Thermoanaerobacter brockii comb. nov., Thermoanaerobacterium thermosulfurogenes comb. nov., and Thermoanaerobacter thermohydrosulfuricus comb. nov., respectively; and transfer of Clostridium thermohydrosulfuricum 39E to Thermoanaerobacter ethanolicus. Int J Syst Bacteriol 43, 41-51.

Lien, T., Madsen, M., Rainey, F. A. \& Birkeland, N.-K. (1998). Petrotoga mobilis sp. nov., from a North Sea oil-producing well. Int J Syst Bacteriol 48, 1007-1013.

Lowe, S. E., Jain, M. K. \& Zeikus, J. G. (1993). Biology, ecology, and biotechnological applications of anaerobic bacteria adapted to environmental stresses in temperature, $\mathrm{pH}$, salinity, or substrates. Microbiol Rev 57, 451-509.

Macy, J. M., Snellen, J. E. \& Hungate, R. E. (1972). Use of syringe methods for anaerobiosis. Am J Clin Nutr 25, 1318-1323.

Maidak, B. L., Olsen, G. J., Larsen, N., Overbeek, R., McCaughey, M. J. \& Woese, C. R. (1996). The Ribosomal Database Project (RDP). Nucleic Acids Res 24, 82-85.

Mesbah, M., Premachandran, U. \& Whitman, W. (1989). Precise measurement of the $\mathrm{G}+\mathrm{C}$ content of deoxyribonucleic acid by high-performance liquid chromatography. Int $J$ Syst Bacteriol 39, 159-167.

Miller, T. L. \& Wolin, M. J. (1974). A serum bottle modification of the Hungate technique for cultivating obligate anaerobes. Appl Microbiol 27, 985-987.

Ollivier, B., Caumette, P., Garcia, J.-L. \& Mah, R. A. (1994). Anaerobic bacteria in hypersaline ecosystems. Microbiol Rev 58, 27-38.

Oren, A. (1986). The ecology and taxonomy of anaerobic halophilic eubacteria. FEMS Microbiol Rev 39, 23-29.

Windberger, E., Huber, R., Trincone, A., Fricke, H. \& Stetter, K. O. (1989). Thermotoga thermarum sp. nov. and Thermotoga neapolitana occurring in African continental solfataric springs. Arch Microbiol 151, 506-512.

Zamost, B. L., Nielsen, H. K. \& Starnes, R. L. (1991). Thermostable enzymes for industrial applications. $J$ Ind Microbiol 8, 71-82.

Zeikus, J. G. (1979). Thermophilic bacteria: ecology, physiology and technology. Enzyme Microb Technol 1, 243-252.

Zhilina, T. N. \& Zavarzin, G. A. (1987). Methanohalobium evestigatum gen. nov., sp. nov., extremely halophilic methaneproducing archaebacteria. Dokl Akad Nauk SSSR 293, 464-468 (in Russian).

Zhilina, T. N., Miroshnikova, L. V., Osipov, G. A. \& Zavarzin, G. A. (1991). Halobacteroides lacunaris sp. nov., new saccharolytic, anaerobic, extremely halophilic organism from the lagoon-like hypersaline lake Chokrak. Mikrobiology (English translation of Mikrobiologiya) 60, 495-503. 